\title{
EUROPEAN UNION, ROMANIA AND RAILWAY TRANSPORT
}

\author{
Clara Elena Mut ${ }^{1}$ \\ Ciprian Beniamin Benea ${ }^{2}$ \\ Adrian Negrea ${ }^{3}$ \\ Secara-Onita Adina ${ }^{4}$ \\ Catarig Andra ${ }^{5}$
}

DOI: https://doi.org/10.31410/ITEMA.2020.143

\begin{abstract}
This paper aims to present the role railway transport plays in European Union and in Romania. The importance of this mode of transport is shortly put to the reader forefronts, while at the same time there is presented its share in land transport market. Road transport has its advantages, but its market share cannot be motivated only by market considerations; there are other factors which put this type of transport on a predominant position. The advantages of rail transport are presented face-to-face with road transport especially for passengers' transport, how railway transport can gain a greater share in land transport market, and how it can contribute to create the conditions of a more sustainable future.
\end{abstract}

Keywords: Railway transport, Land transport, Sustainable future.

\section{INTRODUCTION}

This paper aims to present an analysis with a component focused upon a specific market case in railway transportation area, due to this type of transport's peculiarities in a competitive environment. It will present the railway transportation market regarding passengers' transport, in order to provide clues and development opportunities for this economic activity and to understand the development potential this market has.

As it is the case in other areas, Romania as a European Union member state must bring into harmony its national interest with that of the EU; this is a pressing phenomenon in railway transport area, because the EU's common policy on this subject is focused on the creation of a single railway, as a key-element of European economic integration and a base for future economic development in Europe.

The Romanian railway transport faces great challenges, especially regarding the integration in the European railway system and exploiting opportunities brought by the quality of being a European member; missing determination points to the incapacity to exploit the position and potential offered by the Romanian market, and in the same time reducing the existing discrepancies.

In the last years the Romanian railway transportation system registered numerous changes such as restructuring, liberalization, aspects specific to administrative and legal areas; but in the

SC Interregional SRL - (private railway transport operator)

University of Oradea, Strada Universității nr. 1, Oradea 410087, Romania

University of Oradea, Strada Universității nr. 1, Oradea 410087, Romania

University of Oradea, Strada Universității nr. 1, Oradea 410087, Romania

University of Oradea, Strada Universității nr. 1, Oradea 410087, Romania 
technical area - where upgrading needs huge and sustained efforts - Romanian railway infrastructure continues to be in a visible and continuous decay, placing Romania in a weak position face-to-face with other European states.

As a matter of fact, railway transportation is interconnected with national interest at large, and as a consequence, strategic objectives regarding railway transport system derives from national interest connected to improving national mobility and the state's capacity to administrate better its territory. Railway transport system is a key-component in this regard; from this point of view transportation and geopolitics overlap.

Furthermore, the stimulation of railway transport in order to move persons has become a high priority in the European Union framework, which was underscored by the White Paper in 2001; this strategic document presented the importance and the advantages of railway transportation related to climate changes and environmental protection (White Charta, 2015). Ten years later, the White Paper of 2011 has specified that greenhouse emissions should be reduced by $80-95 \%$ until 2050 related to their level in 1990 (White Charta, 2015). This document presents main steps to be taken in order to rise railway transport efficiency, to rise its competitiveness related to resources' use, and to become a sustainable alternative to road transport.

In Romania, the main direction of development and types of transport's balance promoted both at institutional level, and by active companies operating in the transport sector, sustain national policies in transport sector in correlation with this European strategic document.

Seeing the gap between the situation where the Romanian railway transport system is located and the ascending trend identified in Western Europe in this field of transport, it is of outmost importance to identify the strategies and resources in order to equilibrate the balance among types of transport in Romania, with the aim of reducing pollution, rising mobility, and the decongestion of roads.

The only way to recover and revitalize railway transport must be centered on improving its competitiveness, and in this way, it would become an important part among other continental types of transport, rising its capacity to recover its lost clients, and to attract new ones.

The current situation in Romania points to the fact that there exists a great potential regarding the possibility to rise railway transport share on Romanian domestic transport market for passengers' movement: railway can attract both people which currently use public road transport when traveling between cities, and people which use their car.

Railway transport can become a key-player on domestic transport market, as over 90\% (Development strategy 2018-2020 Ministry of Transport, p. 13) of total railway transport is done on domestic area.

If this would be the case in the future, the success of railway transport on Romanian domestic market, it would strengthen international railway transport, too; this would contribute directly also to the European Union's success related to the creation of European unique railway area. Integration in this unique area is the strategic objective which derives from the quality of being an EU member state. 


\section{CONTEXT AND CHALLENGES}

The importance that the railway has on economic, social and political fields determines all states to develop their domestic transportation systems, and pushes them to collaborate in order to identify border points where these networks meet each other.

The level of transport system's development directly determines the degree and capacity to attract material and human resources located in different areas, territorial repartition of production capacities and their specialization, distribution of urban centers and domestic population, size and shape of human settlements, technological, cultural and scientific development; it improves a country's defense capacity and determines the degree a specific society contributes to globalization. (Gherasim T., 2007, p. 12) Shortly, greater mobility means that in the same span of time the society with greater mobility rotates money faster, creates greater wealth, and brings greater incomes to the national budget, because if the goods/services are sold/bought faster so does the taxes imposed on them are collected faster. In this way, transportation and civilization are the two faces of the same coin.

Public interests connected to transport activity determine governments get involved in this strategic sector. Good or bad public policies in the transport sector are decisive for encouraging or blocking the transportation activity's success. This policy should aim:

- rising efficiency of transport activities;

- be sensitive to market trends and needs;

- attract passengers;

- be affordable and take into account the best environmental standards.

Efficiency in transportation - or its absence - is a central element for economic development - or it can morph into a hindrance for economic development. The best way to rise transport efficiency is to promote the cheap types of transport, as to provide the minimization of logistical costs at domestic level.

The repartition of different types of transport is given by the evolution of different technologies and of economic interests.

The following analysis provides clues to see general distribution of different types of transport in Romania, the data being taken from Romanian National Institute of Statistics, and appraisals made by Romanian Railways Company (CFR). (Development strategy 2018-2020 Ministry of Transport, p. 23)

In Romania, the main share of passengers' transport over land is taken by road transport, $80 \%$ respectively. At European Union level the share of road transport in land transport is $83 \%$, a little higher than in Romania due to higher capacity of Western societies to get access to cars, and a better road infrastructure.

In the following figure, there are presented the specific situations of land transport use in EU, and in Romania respectively. 
Figure 1. Different types of transport's market share in Romania and the EU

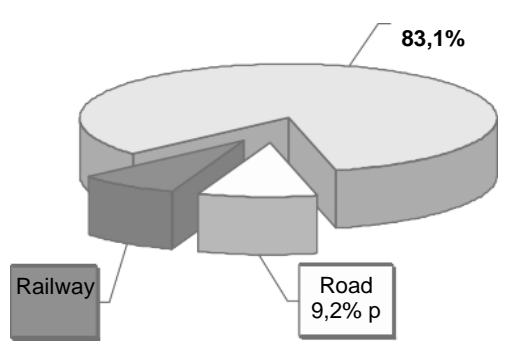

Romania

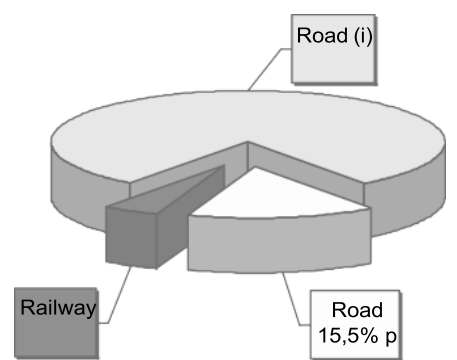

EU

Source: http://mt.ro/web14/documente/acte-normative/2018/07_03/Strategie, accessed at 10.04.2020; Development strategy 2018-2020 Ministry of Transport, p. 24

The mobility requirements of the population overland are distributed between road transport of passengers using their individual transport options (i), and the public transport (p) provided by road transport operators by bus and coach, and of course or by rail transport operators.

The road transport preeminence over railway transport points to the fact that it seems (at first sight) to be superior from an economic point of view and more attractive to transport beneficiaries.

But a study with global perspectives created together with International Railways Union (UIC) and International Energy Agency (IEA) (Railway Handbook 2014, p. 5) indicates that railway transport is much more efficient than road transport (Development strategy 2018-2020 Ministry of Transport, p. 25), because:

- under the energy efficiency perspective, railway uses per transport unit 11 times less energy than road transport;

- from environmental point of view, the costs generated to fight greenhouses gases are very small: railway transport generates only $2 \%$ of greenhouses gases generated by transport sector, while road transport gives 73\% (European Environment Agency); this means 36 times more pollution by cars/buses than railway;

- road is much more dangerous than rail. For road transport it was taken the average of 259 deadly accidents/billion passengers/ km (Transport Master Plan 2014), while for rail transport the average is 1,34 deadly accidents/billion passengers/ km (ERA Report). Road gives 193 times more bad accidents than rail per billion/passengers $/ \mathrm{km}$; as a consequence, medical costs due to road accidents are around Euro 1.2 billion/year only in Romania, meaning $0.8 \%$ of GDP. (Development strategy 2018-2020 Ministry of Transport, p. 27)

As we can observe, rail transport is much more efficient from economic and environmental points of view, and the safest one. As a direct deduction, the optimization of economic activity is better fulfilled when railways get a bigger market share. This means lower costs for national economy, which determines a higher competitiveness on global stage and a stimulus for economic development. (Development strategy 2018-2020 Ministry of Transport, p. 26)

Put it synthetically, national transportation system should be characterized by equilibrium among different types of transport, being capable to assure maximum benefits for national economy and the potential for rising through direct cost reduction and their externalizations; to 
rise energy security, and oil consumption's reduction in transport sector; to reduce negative effects of transport activity upon the environment.

The causes for the present situation where road transport has preeminence is due to political decisions at highest level. Road transport means at first sight freedom - freedom to choose what, how, when and where to travel - while railways means at first sight rigidity and discipline. But in the long run, road transport means a dispersed society which generates higher costs to administrate, while rail means industry and easier and cheaper way to administrate territory and to centralize the forces of society. We can shortly note that even from military point of view rail is far more strategic than road: in geopolitical fight among nations - which is a constant of world politics - railways and fleet fights to control the area close to their meeting points, in world ports, respectively. But as political men are in constant search for votes, they promoted the idea of freedom through the acquisition of a personal car, and ordinary men jump into it fast. This was one of the most important elements which gave road the present position. Of course, the oil industry wants to sell its products, so it needs buyers, more buyers. In this way big oil interests overlapped with political men interests.

But railway transport is of outmost importance, whose advantages could decisively contribute to national transport system's efficiency improving and its sustainability.

Romania's integration in EU and the reduction of gaps among Romania and other EU member states depends on railway transport system's gradual integration in a unique European transport system; the alignment to European policy and strategy in transportation field is not an option, but a necessity. (Development strategy 2018-2020 Ministry of Transport, p. 16)

\section{THE PECULIARITIES OF RAILWAY TRANSPORT OF PASSENGERS IN ROMANIA}

The organization of the Romanian railway transport system is in line with the European policy and legislation in this field, in order to provide an optimal working in a competitive environment; the principle of complete administrative separation of railway infrastructure management and railway transport services is fully applied. The railway operator provides the commercial relation with the client using his own resources, while the management of infrastructure provides necessary activities which sustain train circulation, providing railway infrastructure, too.

The asymmetric public financing of road and rail transports, characterized by funds 10 times smaller for railways (Development strategy 2018-2020 Ministry of Transport, p. 29), has generated a significant competitive loss, because of railway infrastructure's decay, which has severely limited the trains' performances reflected in commercial speed and punctuality.

Great parts of the railway system in Romania have registered constant decay, generating speed limits, while only $40 \%$ of the railway system is electrified (Development strategy 2018-2020 Ministry of Transport, p. 123). The commercial speed limit is around $50 \mathrm{~km} / \mathrm{h}$ for passengers' trains, 40 to $60 \%$ less than the speed for which that railway had been constructed (Development strategy 2018-2020 Ministry of Transport, p. 91).

Due to these deficiencies, it has become a necessity to find a strategy which would define the Romanian railway transport's evolution, taking account of national financial capacities, European financial support, and Romania's national and administrative capacities. 
A great project had been initiated in 2006, regarding the modernization of the rail line between Bucharest and Constanta aiming at rising maximum speed from $140 \mathrm{~km} / \mathrm{h}$ to $160 \mathrm{~km} / \mathrm{h}$, which had been concluded in 2014. Another national project began in 2017 and its purpose is to create the technical capacities along the 4-th European Corridor, to facilitate the jump from $50 \mathrm{~km} / \mathrm{h}$ to $120 \mathrm{~km} / \mathrm{h}$, while between Simeria and Sighisoara the passengers' train would run even with $160 \mathrm{~km} / \mathrm{h}$.

To make business in rail transport in Romania one needs to take into account that there are, from administrative point of view, quite high barriers, due to special and important administrative conditions and expensive investments (licenses, safety certificates, rolling material).

The structure of railway market regarding passengers' transport reflects the specific legislation, both from access to infrastructure point of view, and from the way one can operate on that infrastructure.

The number of private companies is small, because of peculiarities of rail transport and the way it is regulated. The market share of private railway operators is around $20 \%$ in Romania (http://www.consiliulferoviar.ro/, p.85), meaning that this country has one of the top position in Europe, but the market share of rail transport of passengers has significantly been diminishing in the face of road transport (individual or public), nowadays being situated around 16\% (Development strategy 2018-2020 Ministry of Transport, p. 57).

Between 1990 and 2012 the number of railway passengers had been constantly decreasing (from 408 mil passengers $/ \mathrm{km}$ to 54,5 mil passengers $/ \mathrm{km}$ ), but after that it has been registering a constant increase, and in 2019 it had got to 66 mil passengers $/ \mathrm{km}$ (http://www.consiliulferoviar.ro/, p.8).

Romanian railway market has the peculiarities of oligopoly, being dominated by an important leader - CFR Calatori - share of 80 to $86 \%$, and asymmetric quotas, $80 \%$ facing $10-14 \%$, or even less for other operators, put together (http://www.consiliulferoviar.ro/, p.47).

The market structure is characterized by a high concentration using Herfindahl-Hirschman Index (HHI) calculations, which is used to measure the degree of concentration on a specific market. It used the cumulus of square market quotas of all companies on a specific market. A poor concentrated market has an HHI Index smaller than 1000, a medium concentrated one has HHI between 1000 and 2000. Over 2000 the market is a concentrated one and Concentration Ratio (CRk) points to the figure of over 6000 (HHI) and 3\% (CRk), indicating the peculiarities of a strong oligopoly (http://www.consiliulferoviar.ro/, p.47).

A point to be mentioned is the fact that the elasticity of demand is not uniform on the whole market; there are passengers which show different degrees of sensitivities regarding price. The main factors determining such differences are trip's aim, incomes level, or the accessibility (financial and geographical) of another type of transport.

The consumers negotiation's power is reduced, market being characterized by an atomized demand, with a significant number of people without alternatives. The low level of price in comparison with other countries in Western Europe constitutes a hindrance for potential competitors, and doesn't stimulate competition's intensification through rising profitability on the most used networks. 
Graph 1: Regarding the Evolution Herfindahl-Hirschman Index and CR3 and the Degree of Market Concentration

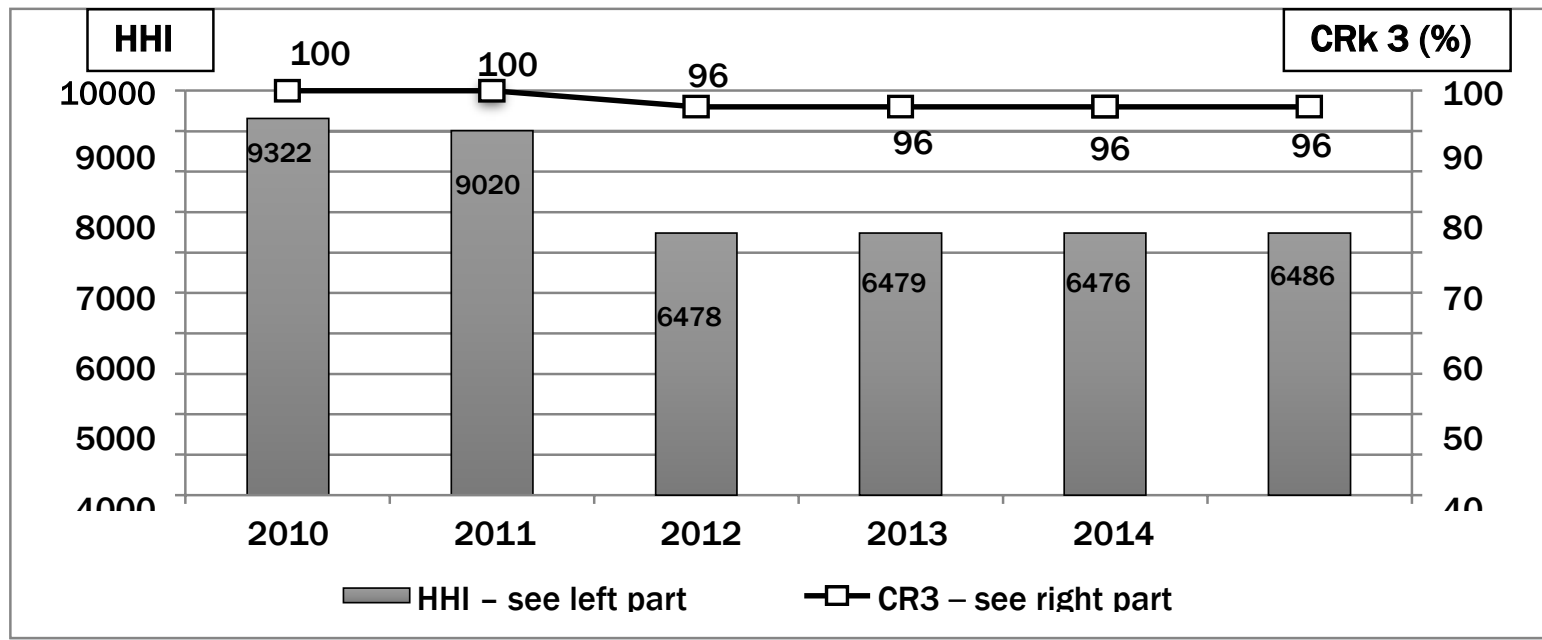

Source: CFR Calatori, http://www.consiliulferoviar.ro/ accessed at 15.03.2020

The degree of market transparency is limited; although the level of tariffs can be observed by competitors; while a significant part of the costs is quite symmetrical, the costs' structure is difficult to identify; the railway transport's dynamic depends even on employees' skills, qualifications, and motivation.

From an economic point of view, the only path for rail transport to regain its central position depends on rising its competitiveness.

In the EU there has been registered a moderate increase in the number of passengers using railway transport, while the situation in Romania is lower than the European average, due to missing investments, and fierce competition for road transport.

From administrative point of view, Romania is well positioned in respect with liberalization degree, but the main disadvantages are brought by decaying railway infrastructure and rolling material.

The demand for railway transport is determined by endogenous and exogenous factors; the endogenous elements are railway infrastructure's quality, the way companies administrate railway transport services, doubled by network density, inter-connectivity, quality of transport services, pricing. Exogenous factors have demographical character, being influenced by the number of people in a specific geographical area, unemployment, incomes level and a commercial character such as number of jobs, touristic activities, and the psychological availability to use a specific type of transport.

\section{CONCLUSION}

The action measures taken by the competition are quite timid due to structural peculiarities in railway transport area, the main one being complicated barriers hindering market entry strategies. But when a specific level of passengers' transport is overcome, the commercial incomes are bigger than the costs, the profit being directly influenced by railway transport activity's intensification. In that moment the railway system would become efficient on commercial base only, without needing to attract public financing. 
But in order to get to this point, there are necessary initial investments in infrastructure, while in order to revitalize railway transport (Development strategy 2018-2020 Ministry of Transport, p. 34), there are needed some measures such as:

- limiting public spending (through subsidies) of road transport, and the internalization of all costs generated by transport activity, including environmental costs;

- creation of necessary prerequisites in order to provide the framework for the railway transport's development, in an open and competitive environment;

- limiting necessary subsidies for railway transport until it gets to its own minimum intrinsic efficiency.

One main premise of European transport policy is: „The continent's prosperity will depend on all European regions' capacities to stay fully integrated in world economy, in a competitive manner. Efficient transports are a vital prerequisite for this." (Development strategy 2018-2020 Ministry of Transport, p. 2)

\section{REFERENCES}

Carta Albă (2015)- Foaie de parcurs pentru un spaţiu european unic al transporturilor - Către un sistem de transport competitiv şi eficient din punct de vedere al resurselor https://eurlex.europa.eu/legal-content/RO/LSU/?uri=celex:52011DC0144

Development strategy 2018-2020, Ministry of Transport, Bucharest, Romania

Gherasim T. (2007) Sisteme de transport, Transporturi feroviare, Editura Bacovia, Bacău, Romania

Railway Handbook (2014) - Energy Consumption and CO2 Emissions - Focus on Infrastructure

European Environment Agency

CFR Calatori, http://www.consiliulferoviar.ro/; Studiu de piaţă în transportul de călători 